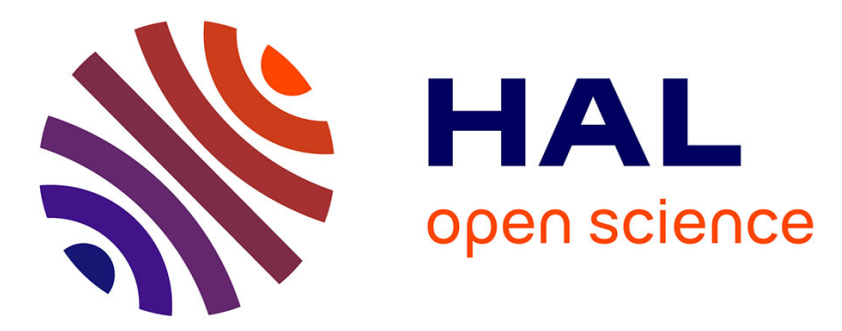

\title{
Reconsidering the role of 'semi-natural habitat' in agricultural landscape biodiversity: a case study
}

Rémi Duflot, Stéphanie Aviron, Aude Ernoult, Lenore Fahrig, Francoise Burel

\section{To cite this version:}

Rémi Duflot, Stéphanie Aviron, Aude Ernoult, Lenore Fahrig, Francoise Burel. Reconsidering the role of 'semi-natural habitat' in agricultural landscape biodiversity: a case study. Ecological Research, 2015, 30 (1), pp.75-83. 10.1007/s11284-014-1211-9 . hal-01120722

HAL Id: hal-01120722

https://hal-univ-rennes1.archives-ouvertes.fr/hal-01120722

Submitted on 26 Feb 2015

HAL is a multi-disciplinary open access archive for the deposit and dissemination of scientific research documents, whether they are published or not. The documents may come from teaching and research institutions in France or abroad, or from public or private research centers.
L'archive ouverte pluridisciplinaire HAL, est destinée au dépôt et à la diffusion de documents scientifiques de niveau recherche, publiés ou non, émanant des établissements d'enseignement et de recherche français ou étrangers, des laboratoires publics ou privés. 
R. Duflot, S. Aviron, A. Ernoult, L. Fahrig, F. Burel (in press). Reconsidering the role of 'semi-natural habitat' in agricultural landscape biodiversity: a case study. Ecological research

Reconsidering the role of 'semi-natural habitat' in agricultural landscape biodiversity: a case study

Rémi Duflot $^{\text {a,b, }}{ }^{,}$, Stéphanie Aviron ${ }^{\mathrm{b}}$, Aude Ernoult ${ }^{\mathrm{a}}$, Lenore Fahrig ${ }^{\mathrm{c}}$, Francoise Burel ${ }^{\mathrm{a}}$ (1)

${ }^{\text {a } U M R ~} 6553$ Ecobio, CNRS, Université de Rennes 1.

Campus de Beaulieu, 35042 Rennes Cedex, France

\footnotetext{
${ }^{\mathrm{b}}$ UR 980 SAD-Paysage, INRA.
}

65 Rue de Saint Brieuc, CS 84215, 35042 Rennes Cedex, France

${ }^{\mathrm{c}}$ Geomatics and Landscape Ecology Research Laboratory, Department of Biology, Carleton University.

1125 Colonel By Drive, Ottawa, Ontario, Canada K1S 5B6

\footnotetext{
* Corresponding author
}

e-mail: duflot.remi@gmail.com

phone: +33-223-236-663 / fax: +33-223-235-026 


\section{ABSTRACT}

Semi-natural habitats are considered as the main source of biodiversity in agricultural landscapes. Most landscape ecology research has focused on the amount (relative surface) and spatial organisation of these habitats. However, these two components of landscape heterogeneity, composition and configuration, are often correlated. Also, landscape structure effects on biodiversity were mostly observed locally, while there is a great need for studying landscape-scale gamma diversity. We conducted a mensurative experiment to determine the independent effects of semi-natural habitat amount and configuration on gamma diversity of carabid beetles and vascular plants. The influence of landscape heterogeneity components were tested on species richness, evenness and composition. Local diversity (species richness and composition) was compared across the various cover types to determine their relative contributions. Only carabid species evenness and composition were influenced by seminatural habitat amount. Carabid and plant species richness and plant species composition remained unaffected by semi-natural habitats. Local diversity analysis showed that three types of habitats can be distinguished in agricultural landscapes: grasslands (temporary and permanent ones), woody habitats (woodlands and hedgerows) and row crops. These results beg for a re-evaluation of the semi-natural covers. Temporary and permanent grasslands are often similar, probably because of comparable farming management. Permanent grasslands and woody habitats are often combined as semi-natural covers, although they support very different communities. The lack of effect of semi-natural habitat amount and configuration on gamma diversity results from a more complex organisation of biodiversity in landscapes and supports the move from semi-natural $v s$. farmland to habitat mosaic landscape representations.

Keywords: carabidae, flora, landscape structure, community, MultiModel Inference 


\section{INTRODUCTION}

Often used as a surrogate for landscape heterogeneity or complexity (e.g. Thies et al. 2003; Tscharntke et al. 2005), the amount of semi-natural cover in an agricultural landscape, a descriptor of landscape composition, has been shown to exert a positive effect on vascular plants, insects, spiders, birds, and small mammals found there (e.g. Benton et al. 2003; Burel et al. 2004; Hendrickx et al. 2007; Billeter et al. 2008). Semi-natural cover types differ from the farmland (crop) covers in that they are relatively permanent, e.g. hedgerows, woodlands, and permanent grasslands and pasture. These semi-natural covers are expected to play an essential role in maintaining biodiversity in many cultivated areas by providing overwintering sites, food resources, refuges, and source populations for re-colonisation of disturbed habitats (Tscharntke et al. 2005; Chaplin-Kramer et al. 2011). In addition, an increasing literature underlines the importance of edges between semi-natural covers and crops (landscape configuration), as they have been shown to enhance local animal and plant species movements and spillovers between adjacent patches (Tscharntke et al. 2007; Brudvig et al. 2009; Blitzer et al. 2012; Concepcion et al. 2012). These movements, are important for habitat complementation (accessibility of multiple required habitat types), source-sink relationships (Dunning et al. 1992) and re-colonization processes, i.e. metapopulation functioning (Hanski 1999). Hence, semi-natural habitats are not only important for their local communities but also contribute to maintain communities of cultivated lands (e.g. 'beetle bank', MacLeod et al. 2004). Semi-natural habitats of different kinds may not host the same community (e.g. permanent grassland vs. woodland) but share the fact of promoting species persistence at the landscape level.

An important issue in studying the effect of landscape heterogeneity on biodiversity is the spatial scale (extent) at which diversity is measured. To date, landscape ecology research has mostly used the focal-patch or focal-site approach, where biodiversity is evaluated at the 
patch, or site, level (alpha diversity - see Thornton et al. 2011 for a review). Such alpha diversity assessment only partially reflects the total diversity of landscapes as different cover types may host different community assemblages (beta diversity). The contribution of beta diversity to the total landscape diversity (gamma diversity) is expected to be dominant over the contribution of alpha diversity (Tscharntke et al. 2012). Hence, biodiversity conservation in agricultural landscapes needs a landscape perspective and the contribution of the various cover types to gamma diversity should be considered.

$$
\text { Commonly, studies evaluate the proportion of semi-natural covers - landscape }
$$
composition - without considering independently its spatial arrangement - landscape configuration - (Millan-Pena et al. 2003; Gabriel et al. 2005; Woodcock et al. 2010). When the configuration of semi-natural covers is explicitly considered (e.g. Hendrickx et al. 2007; Holzschuh et al. 2010; Concepcion et al. 2012), the landscape metrics used to measure it (e.g. proximity index, or total edge length) are usually correlated with habitat amount (Fahrig 2003). Thus, the relative effects of composition and configuration are difficult to estimate independently (Fahrig 2003; Ewers and Didham 2006). However, it is important to identify these independent effects, to determine whether conservation scheme should be aimed at increasing the amount of semi-natural cover in landscapes or at creating a particular spatial pattern of them (Boitani et al. 2007; Lindenmayer and Fischer 2007; Smith et al. 2009). We conducted a mensurative experiment to determine the relative and independent effects of the amount of semi-natural cover (a measure of landscape composition) and the length of edge between semi-natural cover and farmland (a measure of landscape configuration) on biodiversity. We selected twenty $1 \mathrm{~km}^{2}$ landscapes in an agricultural region of western France, such that the correlation between the two landscape descriptors was minimized. Within each landscape we surveyed carabid beetle and vascular plant multihabitat gamma diversity, using a stratified hierarchical sampling design (Crist et al. 2003; 
1 Bennett et al. 2006; Diekotter et al. 2008). Local diversity was compared across the various

cover types of agricultural landscapes to determine the relative contributions of the different covers to the landscape (gamma) diversity. It has already been shown that carabid beetle and plant richness and composition respond to the amount of semi-natural cover in agricultural landscapes (Jeanneret et al. 2003; Millan-Pena et al. 2003; Aviron et al. 2005; Billeter et al. 2008), which make them appropriate species groups for this study.

\section{METHODS}

\section{Study area}

The study was located in an agricultural area in the Ille-et-Vilaine department (6 775 $\mathrm{km}^{2}$ ), Brittany, western France (Fig. 1). The area is dominated by mixed dairy farming. The farmlands are interspersed with woody elements (woodlands and hedgerows), and are comprised of annual crops (mostly winter cereals and maize), and temporary and permanent grasslands. These hedgerow network (bocage) agricultural landscapes were typical of western Europe (Baudry et al. 2000) until the middle of the twentieth century. Over the past 50 years thousands of kilometres of hedgerows have been removed and crop fields have been enlarged to accommodate agricultural intensification (Meeus 1993; Baudry and Papy 2001).

\section{Land-cover data}

Land cover maps were originally created from remote sensing data. An object oriented classification from Landsat TM5 imagery (1ha resolution) was the main source, and permanent grasslands were extracted from a temporal series of MODIS images (COSTEL Land-cover map, Hubert-Moy et al. 2012). For the hedgerows we used data from BD Topo (C) IGN at $50 \mathrm{~cm}$ resolution. The selection of study sites explained below was based on these remote sensing data, but these data were taken in years previous to the actual surveys and had 
relatively low spatial resolution. Therefore, to obtain an accurate description of each selected landscape, we conducted a field survey, and recorded the current land-covers on ArcGIS 9.2 (ESRI). All landscape parameters used in the statistical analyses were then computed from these more precise maps.

\section{Landscape selection}

The map based on remote sensing data was divided into square moving windows of 1 $\mathrm{km}^{2}$, using Chloe 3.1 (Baudry et al. 2006), a routine especially designed for landscape heterogeneity analysis and screening (Baudry and Denis 1995). Within each window / landscape we computed the proportion of each cover type based on the number of pixels, and the length of edge between each cover type combination was measured based on the number of pairs of adjacent pixels (excluding diagonal adjacency). From among all candidate landscapes, we selected those with less than $5 \%$ of land covered by roads, built-up area and water, and with at least $2 \%$ of woodlands and $2 \%$ of permanent grassland to ensure that every landscape contained these cover types. We chose landscapes with similar amounts of woodlands and permanent grasslands $(\mid \%$ Woodlands - \% Permanent Grasslands $\mid<10 \%)$ to avoid an effect due to the dominance of one or the other. In addition, each selected landscape was embedded within a larger area $(3 \mathrm{~km} \times 3 \mathrm{~km})$ with a similar composition $(<10 \%$ difference in any cover type), to ensure that landscape effects would be similar at all biodiversity sampling points. Finally, we selected twenty non-overlapping landscapes across which the correlation between the percentage of semi-natural cover and the length of edge between semi-natural cover and crops was minimized, while maximizing the range of values over each of these gradients. 


\section{Landscape descriptors}

Landscape descriptors for the analyses were based on the precise maps based on field surveys during the sampling year (see above). The amount of semi-natural cover (ranging from 18.7 to $53.8 \%$ ) was used as the landscape composition descriptor and the total length of edge between semi-natural cover and farmland (ranging from 5.5 to $17.3 \mathrm{~km}$ ) as the landscape configuration descriptor. We defined semi-natural cover as woodlands, hedgerows, and permanent grasslands, following the commonly used categorization of cover types in agricultural landscapes (e.g. Bengtsson et al. 2005; Hendrickx et al. 2007; Billeter et al. 2008; Holzschuh et al. 2010). Permanent grasslands were defined as grasslands that are not included in crop rotation for the past 10 years, and identified using time series imaging (see "Landcover data"). Correlation between the two landscape descriptors was low $\left(r_{s}=-0.24\right.$; Fig. 2$)$.

\section{Gamma diversity assessment}

Sampling design

Assessing multi-habitat gamma diversity at the landscape scale requires a hierarchically stratified sampling design (Bennett et al. 2006; Diekotter et al. 2008). In each selected landscape, five cover types (woodland, hedgerow, permanent grassland, temporary grassland, and winter cereal) were sampled. Two patches of each cover types were sampled in each landscape, resulting in ten sample points per landscape (Fig. 1). These patches were chosen randomly, but subject to constraints of farmer authorizations to access fields and hedgerows and ease of accessibility.

\section{Sampling methods}

Carabid beetles were sampled using two pitfall traps per sample point. The traps were positioned $10 \mathrm{~m}$ from the patch margins, except for hedgerows. Traps were collected every 
two weeks, but were only left open for seven consecutive days. There were two sampling seasons: from May to June 2011 (containing four sampling periods), and September 2011 (containing two sampling periods), except for winter cereal patches, which were harvested in July. This sampling regime was designed to encompass the two main seasons during which carabid beetles emerge (Kromp 1999). Data from each trapping period were pooled by sampled patch, and carabid species were identified following (Roger et al. 2010).

At each patch, plant species were sampled using three quadrats, the total area of which corresponded to the minimal recommended sample area for each cover type (MuellerDombois and Ellenberg 1974). These quadrats were distributed along transects from the margin to the centre of the patch, to sample edge and interior species (except for hedgerows). Grasslands and winter cereal crops were sampled using three $2 \mathrm{~m} \times 2 \mathrm{~m}$ quadrats, established at 2, 6 and $10 \mathrm{~m}$ from the patch margin. Woodlands were sampled using three $5 \mathrm{~m} \times 5 \mathrm{~m}$ quadrats separated by $5 \mathrm{~m}$. Hedgerows were sampled using three $5 \mathrm{~m} \times 2 \mathrm{~m}$ quadrats separated by $5 \mathrm{~m}$. Data from the three quadrats were pooled for each sampled patch.

\section{Diversity measures}

\section{Gamma diversity measures}

Data from the 5 cover types (ten sample points in each landscape) were pooled to obtain the total gamma diversity at the landscape level, i.e. the multi-habitat gamma diversity. As biodiversity measures, we used species richness, species evenness and Sorensen dissimilarity index, representing respectively three aspects of community diversity: species number, species dominance and species composition. Species evenness was computed on abundance data for carabid beetles. For plants, we used occurrence data, i.e. within each landscape we assigned a value to every species from 0 to 10 ( 0 indicated absent from the landscape, and 10 indicated present in the 10 sampling points). Species composition 
1 dissimilarities were assessed using pair-wise Sorensen dissimilarity index between all

2 landscape combinations (190 combinations).

3

Local diversity measures

In addition to gamma diversity, species richness and composition were compared between the 5 sampled cover types (habitat) across the 20 studied landscapes. As two patches of each cover types were sampled per landscapes, these analyses included 40 replicates for each cover types.

\section{Statistical analysis}

All statistical tests were performed using R software 3.00 with the "MuMin" package for MMI, "Ade4" for multivariate analysis, "vegan" for dissimilarity analysis, and "Ime4" package for linear mixed models. All descriptors were standardized to make the effect strength of the coefficients comparable across descriptors (Smith et al. 2009; Smith et al. 2011). We checked for normality of descriptors with Shapiro-Wilcoxon tests, Quantile Quantile and Kernel density plots.

Effect of landscape heterogeneity on carabid and plant gamma diversity

We used Multi-Model Inference (MMI) and model averaging to test the effects of the amount of semi-natural cover and the total length of edges between semi-natural cover and farmland on species richness and species evenness. For each analysis there were four possible models, including the null model (see supplements 1 and 2). We computed standardized average linear regression coefficients weighted by the Akaike weights across the "best" models ( $\triangle \mathrm{AICc} \leq 4$, Burnham and Anderson 2002; Smith et al. 2009; Arnold 2010), and 
tested their significance using unconditional $95 \%$ confidence intervals (Burnham and Anderson 2002; Smith et al. 2009).

Landscape heterogeneity effects on species composition were addressed by correlating the Sorensen dissimilarity matrices with distance matrices calculated for each landscape descriptor (Anderson et al. 2011). Each matrix contained the 190 pairwise combinations of the 20 landscapes. The correlations were estimated using the Spearman method as dissimilarity and distance variables were not normally distributed. The correlation significance was determined using a Mantel permutation test (Anderson et al. 2011), which evaluates the null hypothesis of no relationship between distance matrices (based on 9999 permutations).

\section{Comparison of the five sampled cover types}

Species richness of the five sampled cover types was compared using generalized linear mixed models (GLMM) which included landscape as nested factor. For plants, we used a Poisson distribution because data did not follow a Normal distribution.

Species composition of the five sampled cover types was compared using principal components analyses (PCA) on carabid and plant species presence / absence data at the habitat level. The clusters of each of the 5 covers types were then projected on the graphical representation of the two first PCA axes. In addition, a k-means cluster analysis was performed and the obtained classification was compared with the cover types. 5 clusters were looking for as we initially expect a group for each of the 5 sampled cover types.

\section{RESULTS}

Altogether, 106 carabid beetle species and 278 plant species were found. The number of species per landscape (gamma diversity) varied from 36 to 59 (47 on average) for carabid beetles and from 44 to 102 (70.3 on average) for plants. 


\section{Effect of landscape structure on carabid and plant gamma diversity}

Our results revealed no significant effects of semi-natural habitats on carabid species richness, as the coefficient confidence intervals of the percentage of semi-natural cover and the length of edge between semi-natural and farmland cover contained 0 (Fig. 3). However, carabid species relative abundance was significantly less even (lower species evenness) with increasing percentage of semi-natural cover in the landscape (Fig. 3). With an increasing difference between the landscapes in their percentage of semi-natural cover the carabid species composition was increasingly dissimilar, i.e. higher Sorensen dissimilarity $\left(\mathrm{r}_{\mathrm{s}}=0.24\right.$; Mantel test $\mathrm{p}$-value $=0.003$ ). The length of edge between semi-natural and farmland cover had no significant effects on carabid species evenness (Fig. 3) or Sorensen dissimilarity index $\left(r_{\mathrm{s}}=0.04 ;\right.$ Mantel test $\mathrm{p}$-value $\left.=0.358\right)$.

We found no effects of either landscape descriptor on plant species richness or species evenness (Fig. 3). Also, the percentage of semi-natural cover and length of edge between semi-natural and farmland cover had no significant effects on species composition, measured as Sorensen dissimilarity $\left(\mathrm{r}_{\mathrm{s}}=0.01\right.$ and 0.03 ; Mantel test $\mathrm{p}$-value $=0.441$ and 0.392 respectively).

\section{Species richness and species composition across the sampled cover types}

For carabids, the highest species richness was observed in winter cereal fields (although they were sampled for a shorter time) followed by permanent and temporary grasslands while the lowest were found in hedgerows and woodlands (Fig. 4). Particularly, carabid species richness in forest was about half that in winter cereal fields. For plants, the highest species richness was found in hedgerows followed by permanent grasslands which contained one third fewer species; woodlands and temporary grasslands; and winter cereals 
which had the lowest plant species richness at about half the number of species as in hedgerows (Fig. 4).

Regarding species composition, the results were similar for carabids and plants (Fig. 5, Table 1). For both taxa, three main types of communities can be distinguished in the the kmeans cluster analyses (Table 1). Permanent and temporary grassland samples were classified in the same clusters (clusters 2 and 4 for carabids and clusters 1 and 2 for plants). Similarly, woodland and hedgerow samples were often included in the same clusters (clusters 1 and 3 for carabids and clusters 3 for plants). However, for plant, some hedgerows were classified independently from woodland samples (cluster 5). Winter cereal samples were grouped independently for both, carabids and plants (cluster 5 and 4 respectively). These observations are confirmed by the PCA graphical representations (Fig. 5) where grasslands communities (as permanent and temporary grasslands samples overlap), and winter cereal communities can be clearly distinguished. However, hedgerows and woodland samples only partially overlap, especially in the case of plants. Importantly, the two first axes of these PCAs represented only a limited percentage of the total variance, i.e. $10.1 \%$ and $8.2 \%$ (cumulated) for carabids and plants respectively.

\section{DISCUSSION}

\section{Response of gamma diversity to semi-natural covers}

We found that carabid species evenness and composition were affected by the amount of semi-natural cover. The reduction of carabid species evenness with the percentage of seminatural cover was mostly due to a large increase in Poecilus cupreus (L.) abundance in these landscapes. This is somewhat unexpected since P. cupreus is one of the most common openfield species in Europe (Kromp 1999; Holland 2002). We speculate that this species benefited 
1 from an increase in semi-natural cover by using them as overwintering sites. Indeed, $P$.

cupreus is known to use crop fields and semi-natural field margins as complementary habitats (Griffiths et al. 2007). Regarding species composition, it seems that some species, probably forest species, favoured landscape with more semi-natural cover while open field species favoured landscapes where these habitats were less frequent. This interpretation is consistent with previous studies carried out in the same region (Burel et al. 1998; Millan-Pena et al. 2003).

Unlike previous studies (Hendrickx et al. 2007; Billeter et al. 2008; Holzschuh et al. 2010; Concepcion et al. 2012), we found no effect of the amount or spatial organisation of semi-natural covers on species richness of carabids or plants, and no effect on species evenness or composition of plants. These results may be due to a relatively small gradient in semi-natural amount - from 18.7 to $53.8 \%$ (Ekroos et al. 2010; Eigenbrod et al. 2011) compared to most studies that showed a positive effect of the amount of semi-natural cover (e.g. Billeter et al. 2008). The fact that the whole study region is comprised of the same type of farming system may explain this small gradient. In particular, there are no landscapes in our region with an extremely low amount of semi-natural covers $(<10 \%)$. However, for both taxa, gamma species richness varied greatly among landscapes.

\section{Re-evaluation of the semi-natural cover type}

Our results suggest that perhaps in our region the definition of semi-natural covers should be reconsidered. In particular, we considered permanent grasslands, but not temporary grasslands, to be a semi-natural cover. However, in our region, it is not entirely clear whether the permanent grasslands really differ ecologically from temporary grasslands. We found that permanent and temporary grasslands had similar carabid and plant species composition and the average carabid species richness was not significantly different between these two 
grasslands types. We hypothesize that this is due to comparable management of the permanent and temporary grasslands. While permanent grasslands are more stable habitats than temporary grasslands as they are not included in crop rotation, in other respects, agricultural practices such as grazing, mowing, fertilisation and over-sowing with seeds of desirable plants are similar for the two grassland types. These practices are known to affect grasslands plant diversity (Roche et al. 2010; Gaujour et al. 2012) and probably affect arthropod communities as well, including carabid beetles (see Le Roux et al. 2008 for a review). Therefore, grazing, mowing, fertilisation and sowing may have stronger effects, or may be at least as important as the permanence of the grassland. We therefore suggest that permanent and temporary grasslands should be included in the same habitat/cover category for the two studied species groups as it has sometimes been done (e.g. Aviron et al. 2005; Purtauf et al. 2005; Ernoult et al. 2006). An alternative would be to group individual grasslands according to the farming practices actually used in them (e.g. intensive use, intermediate use, extensive use).

The definition of semi-natural covers usually combines woody covers (hedgerows and woodland) with permanent grassland. However, from our results (Fig. 4 and 5) it is clear that woody and grassland cover types contribute differently to carabid and plant gamma diversity. Thus, we suggest that woody (hedgerows and woodlands) and grassy (permanent and temporary grasslands) habitats should be considered as separate cover types when testing the effect of landscape composition and configuration on agricultural landscape gamma diversity. For plants, it may also be important to separate hedgerows from woodlands. Hedgerows had higher species richness than woodlands (Fig. 4), and somewhat different species composition (Table 1, Fig. 5), probably because of a more developed herbaceous stratum in the former. 


\section{CONCLUSION}

Our results contrast with our initial expectation that the amount and the spatial configuration of semi-natural cover would have large effects on agricultural landscape diversity. The use of the 'semi-natural' cover type arose initially from a binary habitat/matrix landscape representation, which often dominates in the literature (Fahrig et al. 2011). In this framework, semi-natural covers (suitable habitat) are expected to support biodiversity while farmlands (matrix) are seen as a hostile environment because of the intensity and frequencies of anthropogenic disturbances (Fahrig et al. 2011). However, in the present study, we found three cover types (grassy, woody and winter cereal covers) that represent habitats for different carabid and plant communities, each of them contributing to the total gamma diversity. This suggests that important information about the ecological responses of these taxa to landscape structure is lost if semi-natural covers are grouped together into a single land cover category. Our results support the move to a 'habitat mosaic' representation of landscapes (Duelli 1997; Fahrig et al. 2011), which considers the diversity of landscape covers, including cultivated ones. For instance, habitat or crop diversity has been shown to increase plant, vertebrate and invertebrate diversity (Robinson et al. 2001; Benton et al. 2003; Poggio et al. 2010; Woodcock et al. 2010). Also, this representation allows accounting with the spatial pattern of the whole landscape. For example, the diversity of habitats creates a diversity of edges which potentially have various ecological functions such as facilitation of dispersal and access to complementary habitats (Macfadyen and Muller 2013). Importantly, the 'habitat mosaic' landscape representation is adaptable as the categorization of cover types can be define according to their functions, or perception by different species or group of species (Fahrig et al. 2011). 
R. Duflot benefited from a PhD grant from Institut National de la Recherche

3 Agronomique (INRA) and Centre National de la Recherche Scientifique - Institut Ecologie et

4 Environnement (CNRS-InEE). Additional financial support was provided by the DIVA-

5 Corridor research project from the French Ministry of Ecology. Our research also benefited

6 from the Zone-Atelier Armorique, which is financially supported by INRA and CNRS-InEE.

7 The collaboration with L. Fahrig was supported by the International Doctorate College of the

8 European University of Brittany and the Brittany region. We thank J. Nabucet from CNRS

9 research team LETG - Costel (Littoral, Environnement, Télédétection, Géomatique) for his

10 work on the production of maps and Y. Rantier for its support in GIS data analysis. 


\section{REFERENCES}

Anderson M. J., Crist T. O., Chase J. M., Vellend M., Inouye B. D., Freestone A. L., Sanders N. J., Cornell H. V., Comita L. S., Davies K. F., Harrison S. P., Kraft N. J. B., Stegen J. C. \& Swenson N. G. (2011) Navigating the multiple meanings of beta diversity: a roadmap for the practicing ecologist. Ecology Letters 14: 19-28.

Arnold T. W. (2010) Uninformative parameters and model selection using Akaike's information criterion. Journal of Wildlife Management 74: 1175-1178.

Aviron S., Burel F., Baudry J. \& Schermann N. (2005) Carabid assemblages in agricultural landscapes: impacts of habitat features, landscape context at different spatial scales and farming intensity. Agriculture Ecosystems \& Environment 108: 205-217.

Baudry J., Bunce R. G. H. \& Burel F. (2000) Hedgerows: An international perspective on their origin, function and management. Journal of Environmental Management 60: 7-22. Baudry J. \& Denis D. (1995) Chloé : Utilitaire d'analyse de l'hétérogénéité d'une image ; (fichiers image IDRISI). Rennes, INRA, SAD-Armorique.

Baudry J. \& Papy F. (2001) The role of landscape heterogeneity in the sustainability of cropping systems. In: Crop Science-Progress and Prospects (eds. J. Nösberger, H. H. Geiger \& P. C. Struik) pp. 243-259. Cabi Publishing, Oxon.

Baudry J., Schermann N. \& Boussard H. (2006) Chloe 3.1: freeware of multi-scales analyses. INRA, SAD-Paysage.

Bengtsson J., Ahnstrom J. \& Weibull A. C. (2005) The effects of organic agriculture on biodiversity and abundance: a meta-analysis. Journal of Applied Ecology 42: 261-269.

Bennett A. F., Radford J. Q. \& Haslem A. (2006) Properties of land mosaics: Implications for nature conservation in agricultural environments. Biological Conservation 133: 250-264. Benton T. G., Vickery J. \& Wilson J. (2003) Farmland biodiversity: is habitat heterogeneity the key? Trends in Ecology \& Evolution 18: 182-188.

Billeter R., Liira J., Bailey D., Bugter R., Arens P., Augenstein I., Aviron S., Baudry J., Bukacek R., Burel F., Cerny M., De Blust G., De Cock R., Diekotter T., Dietz H., Dirksen J., Dormann C., Durka W., Frenzel M., Hamersky R., Hendrickx F., Herzog F., Klotz S., Koolstra B., Lausch A., Le Coeur D., Maelfait J. P., Opdam P., Roubalova M., Schermann A., Schermann N., Schmidt T., Schweiger O., Smulders M. J. M., Speelmans M., Simova P., Verboom J., van Wingerden W., Zobel M. \& Edwards P. J. (2008) Indicators for biodiversity in agricultural landscapes: a pan-European study. Journal of Applied Ecology 45: 141-150. Blitzer E. J., Dormann C. F., Holzschuh A., Klein A. M., Rand T. A. \& Tscharntke T. (2012) Spillover of functionally important organisms between managed and natural habitats. Agriculture Ecosystems \& Environment 146: 34-43.

Boitani L., Falcucci A., Maiorano L. \& Rondinini C. (2007) Ecological networks as conceptual frameworks or operational tools in conservation. Conservation Biology 21: 14141422.

Brudvig L. A., Damschen E. I., Tewksbury J. J., Haddad N. M. \& Levey D. J. (2009) Landscape connectivity promotes plant biodiversity spillover into non-target habitats. Proceedings of the National Academy of Sciences of the United States of America 106: 93289332.

Burel F., Baudry J., Butet A., Clergeau P., Delettre Y., Le Coeur D., Dubs F., Morvan N., Paillat G., Petit S., Thenail C., Brunel E. \& Lefeuvre J. C. (1998) Comparative biodiversity along a gradient of agricultural landscapes. Acta Oecologica-International Journal of Ecology 19: 47-60.

Burel F., Butet A., Delettre Y. R. \& de la Pena N. M. (2004) Differential response of selected taxa to landscape context and agricultural intensification. Landscape and Urban Planning 67: 195-204. 
Burnham K. P. \& Anderson D. R. (2002) Model selection and Multi-Model Inference. A practical information-theoretic Approach. Springer-Verlag, New York, USA. Chaplin-Kramer R., O'Rourke M. E., Blitzer E. J. \& Kremen C. (2011) A meta-analysis of crop pest and natural enemy response to landscape complexity. Ecology Letters 14: 922-932. Concepcion E. D., Fernandez-Gonzalez F. \& Diaz M. (2012) Plant diversity partitioning in Mediterranean croplands: effects of farming intensity, field edge, and landscape context. Ecological Applications 22: 972-981.

Crist T. O., Veech J. A., Gering J. C. \& Summerville K. S. (2003) Partitioning species diversity across landscapes and regions: A hierarchical analysis of alpha, beta, and gamma diversity. American Naturalist 162: 734-743.

Diekotter T., Billeter R. \& Crist T. O. (2008) Effects of landscape connectivity on the spatial distribution of insect diversity in agricultural mosaic landscapes. Basic and Applied Ecology 9: 298-307.

Duelli, P. (1997). Biodiversity evaluation in agricultural landscapes: An approach at two different scales. Agriculture Ecosystems \& Environment, 62, 81-91.

Dunning J. B., Danielson B. J. \& Pulliam H. R. (1992) Ecological processes that affect populations in complex landscapes. Oikos 65: 169-175.

Eigenbrod F., Hecnar S. J. \& Fahrig L. (2011) Sub-optimal study design has major impacts on landscape-scale inference. Biological Conservation 144: 298-305.

Ekroos J., Hyvonen T., Tiainen J. \& Tiira M. (2010) Responses in plant and carabid communities to farming practises in boreal landscapes. Agriculture Ecosystems \& Environment 135: 288-293.

Ernoult A., Tremauville Y., Cellier D., Margerie P., Langlois E. \& Alard D. (2006) Potential landscape drivers of biodiversity components in a flood plain: Past or present patterns?

Biological Conservation 127: 1-17.

Ewers R. M. \& Didham R. K. (2006) Confounding factors in the detection of species responses to habitat fragmentation. Biological Reviews 81: 117-142.

Fahrig L. (2003) Effects of habitat fragmentation on biodiversity. Annual Review of Ecology Evolution and Systematics 34: 487-515.

Fahrig L., Baudry J., Brotons L., Burel F. G., Crist T. O., Fuller R. J., Sirami C., Siriwardena G. M. \& Martin J. L. (2011) Functional landscape heterogeneity and animal biodiversity in agricultural landscapes. Ecology Letters 14: 101-112.

Gabriel D., Thies C. \& Tscharntke T. (2005) Local diversity of arable weeds increases with landscape complexity. Perspectives in Plant Ecology Evolution and Systematics 7: 85-93. Gaujour E., Amiaud B., Mignolet C. \& Plantureux S. (2012) Factors and processes affecting plant biodiversity in permanent grasslands. A review. Agronomy for Sustainable Development 32: 133-160.

Griffiths G. J. K., Winder L., Holland J. M., Thomas C. F. G. \& Williams E. (2007) The representation and functional composition of carabid and staphylinid beetles in different field boundary types at a farm-scale. Biological Conservation 135: 145-152.

Hanski I. (1999) Metapopulation ecology. Oxford University Press, New York, USA. Hendrickx F., Maelfait J. P., Van Wingerden W., Schweiger O., Speelmans M., Aviron S., Augenstein I., Billeter R., Bailey D., Bukacek R., Burel F., Diekotter T., Dirksen J., Herzog F., Liira J., Roubalova M., Vandomme V. \& Bugter R. (2007) How landscape structure, landuse intensity and habitat diversity affect components of total arthropod diversity in agricultural landscapes. Journal of Applied Ecology 44: 340-351.

Holland J. M. (2002) Carabid beetles: their ecology, survival and use in agroecosystems. In: The agroecology of carabid beetles (ed. J. M. Holland) pp. 1-40. Intercept Press, Andover, UK. 
Holzschuh A., Steffan-Dewenter I. \& Tscharntke T. (2010) How do landscape composition and configuration, organic farming and fallow strips affect the diversity of bees, wasps and their parasitoids? Journal of Animal Ecology 79: 491-500.

Hubert-Moy L., Nabucet J., Vannier C. \& Lefebvre A. (2012) Mapping ecological continuities: which data for which territorial level? Application to the forest and hedge network. International Journal of Geomatics and Spatial Analysis 22: 619-640. Jeanneret P., Schupbach B. \& Luka H. (2003) Quantifying the impact of landscape and habitat features on biodiversity in cultivated landscapes. Agriculture Ecosystems \& Environment 98: 311-320.

Kromp B. (1999) Carabid beetles in sustainable agriculture: a review on pest control efficacy, cultivation impacts and enhancement. Agriculture Ecosystems \& Environment 74: 187-228.

Le Roux X., Barbault R., Baudry J., Burel F., Doussan I., Garnier E., Herzog F., Lavorel S., Lifran R., Roger-Estrade J., Sarthou J. P. \& Trommetter M. (2008) Agriculture et biodiversité. Valoriser les synergies. Expertise scientifique collective. Rapport INRA (France).

Lindenmayer D. B. \& Fischer J. (2007) Tackling the habitat fragmentation panchreston. Trends in Ecology \& Evolution 22: 127-132.

Macfadyen S. \& Muller W. (2013) Edges in Agricultural Landscapes: Species Interactions and Movement of Natural Enemies. Plos One 8.

MacLeod, A., Wratten, S.D., Sotherton, N.W. \& Thomas, M.B. (2004) 'Beetle banks' as refuges for beneficial arthropods in farmland: long-term changes in predator communities and habitat. Agric. For. Entomol., 6, 147-154.

Meeus J. H. A. (1993) The transformation of agricultural landscapes in Western-Europe. Science of the Total Environment 129: 171-190.

Millan-Pena N., Butet A., Delettre Y., Morant P. \& Burel F. (2003) Landscape context and carabid beetles (Coleoptera : Carabidae) communities of hedgerows in western France. Agriculture Ecosystems \& Environment 94: 59-72.

Mueller-Dombois D. \& Ellenberg H. (1974) Aims and Methods of Vegetation Ecology. Wiley International Edition, London.

Poggio S. L., Chaneton E. J. \& Ghersa C. M. (2010) Landscape complexity differentially affects alpha, beta, and gamma diversities of plants occurring in fencerows and crop fields. Biological Conservation 143: 2477-2486.

Purtauf T., Roschewitz I., Dauber J., Thies C., Tscharntke T. \& Wolters V. (2005) Landscape context of organic and conventional farms: Influences on carabid beetle diversity. Agriculture Ecosystems \& Environment 108: 165-174.

Robinson R. A., Wilson J. D. \& Crick H. Q. P. (2001) The importance of arable habitat for farmland birds in grassland landscapes. Journal of Applied Ecology 38: 1059-1069.

Roche B., Lanoë E., Le Coeur D., Thenail C. \& Martel G. (2010) Diversité des systèmes de polyculture élevage et des modes d'exploitation des prairies : quelles conséquences sur la diversité végétale? Rencontres recherches ruminants http://www.journees3r.fr/spip.php?article2973.

Roger J.-L., Jambon O. \& Bouger G. (2010) Clé de détermination des carabidés : Paysages agricoles de la Zone Atelier d'Armorique. Laboratoires INRA SAD-Paysage et CNRS ECOBIO, Rennes, France.

Smith A. C., Fahrig L. \& Francis C. M. (2011) Landscape size affects the relative importance of habitat amount, habitat fragmentation, and matrix quality on forest birds. Ecography 34: 103-113.

Smith A. C., Koper N., Francis C. M. \& Fahrig L. (2009) Confronting collinearity: comparing methods for disentangling the effects of habitat loss and fragmentation. Landscape Ecology 24: 1271-1285. 
1 Thies C., Steffan-Dewenter I. \& Tscharntke T. (2003) Effects of landscape context on

2 herbivory and parasitism at different spatial scales. Oikos 101: 18-25.

3 Thornton D. H., Branch L. C. \& Sunquist M. E. (2011) The influence of landscape, patch, and 4 within-patch factors on species presence and abundance: a review of focal patch studies.

5 Landscape Ecology 26: 7-18.

6 Tscharntke T., Bommarco R., Clough Y., Crist T. O., Kleijn D., Rand T. A., Tylianakis J. M., 7 Nouhuys S. v. \& Vidal S. (2007) Conservation biological control and enemy diversity on a 8 landscape scale. Biological Control 43: 294-309.

9 Tscharntke T., Klein A. M., Kruess A., Steffan-Dewenter I. \& Thies C. (2005) Landscape 10 perspectives on agricultural intensification and biodiversity - ecosystem service management. 11 Ecology Letters 8: 857-874.

12 Tscharntke T., Tylianakis J. M., Rand T. A., Didham R. K., Fahrig L., Batary P., Bengtsson J., Clough Y., Crist T. O., Dormann C. F., Ewers R. M., Frund J., Holt R. D., Holzschuh A., Klein A. M., Kleijn D., Kremen C., Landis D. A., Laurance W., Lindenmayer D., Scherber C., Sodhi N., Steffan-Dewenter I., Thies C., van der Putten W. H. \& Westphal C. (2012) Landscape moderation of biodiversity patterns and processes - eight hypotheses. Biological Reviews 87: 661-685.

Woodcock B. A., Redhead J., Vanbergen A. J., Hulmes L., Hulmes S., Peyton J., Nowakowski M., Pywell R. F. \& Heard M. S. (2010) Impact of habitat type and landscape structure on biomass, species richness and functional diversity of ground beetles. Agriculture Ecosystems \& Environment 139: 181-186. 


\section{TABLES}

2

\section{Table 1}

4 Classification matrix for the five sampled cover-types obtained by k-means cluster analysis.

5 W: woodland, H: hedgerow, P and T: permanent and temporary grassland and C: winter $6 \quad$ cereal crop

Carabids

\begin{tabular}{rrrrrr}
\hline \multicolumn{7}{c}{ Cover types } & & & \\
Cluster & W & H & P & T & C \\
\hline 1 & 14 & 9 & 0 & 0 & 0 \\
2 & 0 & 0 & 8 & 15 & 1 \\
3 & 25 & 23 & 4 & 0 & 0 \\
4 & 0 & 6 & 27 & 25 & 2 \\
5 & 1 & 2 & 1 & 0 & 37 \\
Total & 40 & 40 & 40 & 40 & 40 \\
\hline
\end{tabular}

Plants

\begin{tabular}{rrrrrr}
\hline \multicolumn{7}{c}{ Cover types } & & & \\
Cluster & W & H & P & T & C \\
\hline 1 & 0 & 0 & 24 & 9 & 0 \\
2 & 0 & 0 & 15 & 31 & 1 \\
3 & 40 & 12 & 0 & 0 & 0 \\
4 & 0 & 0 & 1 & 0 & 39 \\
5 & 0 & 28 & 0 & 0 & 0 \\
Total & 40 & 40 & 40 & 40 & 40 \\
\hline
\end{tabular}




\section{FIGURE CAPTIONS}

2

3

4

5

6

\section{Figure 1}

(a) map of the study area, (b) representation of the hierarchical sampling design for one of the $1 \mathrm{~km}^{2}$ selected landscapes, and (c) localisation of the study area in France. The sampled cover types are $\mathrm{W}$ : woodland, $\mathrm{H}$ : hedgerow, P: permanent grassland, T: temporary grassland, C: winter cereal crop.

\section{Figure 2}

Total length of edge between semi-natural habitat $(\mathrm{SNH})$ and farmlands $(\mathrm{km})$ plotted against the proportion of the landscape in semi-natural habitat. Points are the 20 selected landscapes. Dotted lines represent the least squares relationships (not significantly different from zero: $r_{\mathrm{s}}$ $=-0.24)$.

\section{Figure 3}

Linear regression coefficients for the effects of proportion of semi-natural habitat (\% SNH) and length of edge between semi-natural habitats and farmlands (SNH - Farmland) on carabid beetle species richness (a) and evenness (b), and vascular plant species richness (c) and evenness (d). Points are the standardized averaged coefficients (weighted by the model's Akaike weight) and error bars are the associated $95 \%$ unconditional confidence limits from MMI analysis. Models with $\Delta \mathrm{AICc}<4$ were included in the averaging (all supported models are reported in supplements 1 and 2). Landscape descriptors whose confidence intervals exclude zero can be considered as having a significant positive (above zero) or negative (below zero) effect. 


\section{$1 \quad$ Figure 4}

2 Average species richness of carabid beetles (a) and vascular plant (b) in the five sampled

3 cover types (40 replicates for each type). Letters indicate significant differences, calculated

4 from generalized linear mixed models (GLMM) that included landscapes as nested factor.

5 Error bars are standard errors of the means.

6

$7 \quad$ Figure 5

8 Graphical representation of the first two PCA axes computed on carabid beetle (a) and plant

9 (b) species presence / absence data. Points are grouped by sampling cover type. W: woodland,

$10 \mathrm{H}$ : hedgerow, P: permanent grassland, T: temporary grassland, C: winter cereal crop (40

11 replicates for each type). Numbers represent the percentage of variance explained by each 12 axes. 